\title{
A Relatividade na Organização (*)
}

\section{Luiz Octavio Beltrão Neiva}

Numa ciência humana as generalizações são condicionais.

BeAtriz M. DE S. WAHRLich

O trabalho que vai descrito a seguir é, genèricamente, fruto de muitas observações pessoats, colhidas durante quase utm decênio nos meus estudos e planejamentos em várias emprêsas da administração pública e particular. Especificamente, porém, êle se destinou à minha defesa de tese nesse último concurso para Técnico de Administração do Serviço Público Federal.

Algumas revisões foram feitas, antes de ilustração e de forma, que de conteúdo.

Minhas pretensões não foram outras que a de apresentar um trabalho original, visto, pelo menos, sob novos ângulos. Aguardarei, dos que me derem a honta de estudá-lo, perguntas e sugestões que saberei conservar e transmitir oportunamente. Estou certo de que meus esforços nesse estágio de minha vida profissional sòmente estarão terminados quando merecer dos leitores de tão conceituada Revista as atenções com que me brindaram os ilustres examinadores dêste trabalho, Professêres Beatriz M. de Souza Wahrlich e Othon Sérvulo DE VAsConcellos, e muito particularmente do dignissimo diretor da "Revista do Serviço Público".

\section{I - JUSTIFICATIVA DO TRABALHO}

$\mathrm{N}$

Ão nos preocupou neste breve ensaio qualquer esfôrço que tentasse modificar aspectos da teoria da Organização ou viesse contribuir para o esclarecimento de pontos-de-vista já emitidos por estudiosos dessa matéria. Igualmente não foi nossa intenção con-

(*) Tese apresentada ao Concurso de Técnico de Administração do S.P.F. 
tribuir para a disciplinação de critérios já adotados e, geralmente, aceitos na prática.

A idéia de elaborar um trabalho da natureza do que ora apresentamos surgiu há três anos, quase simultâneamente, portanto, à divulgação da obra de Rudolf BielschowsKy, "A Relatividade na Economia", prefaciada pelo Professor Hermann Goergen, deputado federal da Alemanha Ocidental, em 22 de fevereiro de 1959. Simplesmente não nos atrevêramos àquela época, já por considerarmos audacioso o assunto, como porque nos faltava, também, a experiência que hoje nos deixa mais à vontade.

Sentimos grande necessidade de limitar perfeitamente o que vamos defender, para que nenhuma dúvida seja levantada quanto às nossas exatas pretensões. Entendemos que a Organização é uma parte de todo e qualquer ramo do conhecimento humano, e que dela não pode prescindir o homem, como ser que a instituiu em função de suas crescentes necessidades, numa tentativa de tornar mais suportáveis as condições de vida em sociedade. Dentro dessa concepção, estaríamos sobrecarregando demasiadamente nossas responsabilidades neste trabalho, se focalizássemos todos os diferentes aspectos que merecem as atenções dos estudiosos de Organização. Sendo assim, limitamos nossa tese a um minimo de aspectos da teoria, ilustrando-os com alguns exemplos práticos, sem nos atrevermos a focalizar outros mais complexos, por julgar inoportuna qualquer conclusão baseada em conceitos muito subjetivos.

$\mathrm{Na}$ elaboração de nosso trabalho baseamo-nos no fato de que existe a imperiosa necessidade de reconhecer, dentro da Organização, em alguns aspectos seus que julgamos mais conhecidos e mais quotidianos, a relatividade que lhes é inerente e que os acompanha no seu permanente evolver. Estaremos reconhecidos, sem dúvida, se estivermos contribuindo para a formação de uma mentalidade, especialmente naqueles que têm por responsabilidade a criação, a combinação, o arranjo e o uso dos diferentes elementos que integram um organismo, se é que pretendem despertar para a solução do problema de tornar mais humanas tôdas as associações de que é uma constante - o Homem.

Gostariamos de deixar bem claro, ainda, que se algumas vêzes emitimos conceitos subjetivos foi por que não poderíamos abandonar de todo o principal fundamento de nosso trabalho, isto é, aquêle que identifica dentro da Organização um fruto que também é dela mesma - sua Relatividade.

$\mathrm{E}^{\prime}$ indispensável a compreensão, finalmente, de que os conceitos aqui emitidos não foram criados sòmente para êste trabalho. Êles existiram e sempre hão de existir. 


\section{II — INTRODUÇÃO}

Tudo no Universo é relativo. A Biblia atribui o início de uma evolução universal a duas fôrças contrárias que só têm razão de existência quando se comparam ou se fundem. A essas fôrças os antigos denominaram Adham (Adão) e Ava (Eva), respectivamente traduzidos no hebraico, positivo e negativo. Realmente só poderíamos entender o positivo se identificássemos o negativo, e vice-versa. Como entender a luz se não admitirmos a sombra? Como identificar o fogo se não conhecermos a água? Tôda e qualquer concepção de tudo o que foi criado sòmente encontra razão de ser nessa elementar comparação.

Duas outras formas foram criadas pelos antigos para ex pressar a dinâmica universal, nos têrmos Caim (Coesão) e Abel (Expansão). Aquela dinâmica se deu, justamente, quando as fôrças de coesão superaram as de expansão, abrindo assim novos horizontes para a humanidade inteira.

A expressão materializada pelo gênio de Albert EINSTEIN (1) representa mais do que um simples fenômeno físico. Ela transcende êsses limites para expressar tôda a dinâmica do comportamento universal. Quando o conhecimento adquirido, ou saber, é impulsionado por uma ação, ou fazer, o produto dêsse comportamento há de resultar uma energia que se traduz por uma evolução. Essa energia é, invariàvelmente, a responsável pela dinâmica em existência .

Mas o que determinou a ação do homem?

Ser mais evoluído dentre os demais, êle tem a capacidade de projetar-se para fora de si mesmo e, gradativamente, conquistar o universo de que é, também, uma parte. Suas atitudes mentais e sua conduta se orientam em função de suas necessidades. Assim, o homem capta, utiliza, modifica e projeta as energias indispensáveis ao seu próprio equilibrio. Quando o organismo se desequilibra, o homem vai buscar os recursos necessários a uma restauração, movendo-se por ações instintivas ou agindo racionalmente. Se tem fome, o instinto o leva ao alimento capaz de saciá-la; se, todavia, êle orienta seu pensamento no śentido de realizar para satisfazer, sua ação é racional.

Tendo o homem criado $\mathrm{a}$ organizaçẳo em que vive, busca aperfeiçoá-la permanentemente, lançando mão de todos os recursos possiveis já atingidos pelo seu conhecimento, numa tentativa de estabelecer relações mais compativeis com a natureza humana, entre todos os que habitam a mesma coletividade.

Mas o que é a Organização?

(1) Einstein, Albert - A expressão $\mathrm{V}=\mathrm{M} \times \mathrm{C}^{2}$ seria traduzida, também, para interpretar a evolução do comportamento humano. 
“... a Organização não é tudo no mundo, mas a base de tudo". (2) Admitimos que assim seja, porque a entendemos uma técnica e não uma ciência. Para esta última, a finalidade principal é voltada para o conhecimento de verdades que devem ser aceitas como tal em tôdas as situações. Acreditamos que a busca à verdade não seja objetivo da Organização. Entendemo-la:

o arranjo das diversas partes de um todo, numa tentativa de torná-las contemporâneamente coerentes, no espaço e no tempo de sua existência.

Sendo assim, não pretendemos buscar a verdade em coisa alguma, mas a situação tanto quanto possível ideal, que permita ao organismo atingir seus objetivos dentro de um funcionamento razoável, mediante o emprêgo de recursos mentais, materiais e energéticos de que dispõe no momento ou tem a capacidade de adquirir. Verdadeiramente, a Organização se utiliza de leis, de principios e de conhecimentos especificos a várias ciências, mas não pretende construir um mosaico científico. Contribuindo para a metodização de diferentes campos do conhecimento humano, ela é, por si mesma, um instrumento de trabalho de que nos servimos para atingir, racionalmente, nossos objetivos.

Torna-se evidente, portanto, que a Organização tem por finalidade máxima a racionalização, e o racional não é, necessàriamente, a expressão da verdade, isto é, não é válido em tôdas as situações. O que pode ser racional para um, segundo circunstâncias, fatos e elementos, pode não ser para outro. O empresário que adquire um equipamento eletrônico pode julgar racional êsse procedimento, considerando a inoperância do seu equipamento convencional. Isso não lhe permite concluir, todavia, que todo equipamento convencional deva ser substituido por outro eletrônico. Tudo é muito relativo, e as verdade não podem deixar margens a qualquer dúvida. Poder-se-ia argumentar com "verdades condicionadas", isto é, sob determinadas condições, admite-se por verdadeiro um fato. Evidentemente, estariamos fragmentando demais as situações para concluirmos pelas verdades. E' bem sabido que não existem duas situações absolutamente idênticas e que todo esfôrço no sentido de se atingir a verdade na Organização há de ficar condicionado por um relativismo que é preciso considerar.

(2) A. Nogueira DE Faria - Estrututa das Organizaçóes Econômicas, pág. 15. 


$$
\text { III - DIVISÃO DO TRABALHO }
$$
forma:

Para efeitos didáticos dividimos nosso trabalho da seguinte

1. a relatividade na terminologia

2. a relatividade na técnica do planejamento:

2.1 - de estruturação de um organismo;

2.2 - em função da seleção de recursos humanos e materiais;

2.3 - de rotinas, métodos e sistemas;

2.4 - referente à determinação de padrões de desempenho;

3. a relatividade nas decisões

4. a relatividade na chefia

5. a relatividade nos custos da produção

6. a relatividade na centralização, descentralização e delegação

7. a relatividade nos principios de organização:

7.1 - divisão do trabalho;

7.2 - simplicidade;

7.3 - coordenação;

7.4 - contrôle;

7.5 - emulação;

7.6 - especialização

\section{IV - DESENVOLVIMENTO DO TRABALHO}

\section{A relatividade na terminlogia}

A questão terminológica sempre preocupou os homens voltados para a pesquisa de diferentes aspectos do conhecimento humano. Designar uma particularidade descoberta não é tarefa das mais fáceis. Não raras vêzes empregamos têrmos que expressam o mesmo fato, fenômeno ou elemento, o que nem sempre permite a identificação simples e rápida daquilo que desejamos transmitir ou assimilar.

A Organização se utiliza do conhecimento próprio a várias ciências, sujeitando-se, de certa forma, aos têrmos ali empregados.

Para se ter uma idéia de como está a questão terminológica também na Organização, gostariamos de citar um trabalho que o Professor Cesar Cantanhede chama de "A exata terminologia em Organização". (3) Iniciando sua exposição, êle se refere ao

(3) A exata terminologia em organização - Publicação da Revista do Serviço Público - 1947, págs. 5/13. 
têrmo "scientific management", traduzido para a lingua portuguêsa por "administração científica", "organização cientififca" e "organização cientifica do trabalho". E comenta a seguir:

“... nunca se ouviu falar em física científica ou biologia científica. Se são ciências, não necessitam a companhia dêsse qualificativo". (4)

Mas é o mesmo Cesar Cantanhede, quando procura interpretar a expressão "ciência do preço de custo", quem afirma:

"A meu ver, entretanto, é essa caracterização a mais importante na organização científica".

E, logo a seguir:

"Outros princípios em que se baseia a organização científica do trabalho: ..." (6)

Cesar Cantanhede se refere, também, a diferentes definições do têrmo "Organização", e que bem demonstram o quanto de relativo pode ocorrer na interpretação de um mesmo assunto. O trecho é o seguinte:

"Tanto pode ser, como dizem Mooney e ReILey: ... a forma de qualquer associação humana para a obtenção de fins comuns, ou segundo $H$. Dutron: ... a a arte de aplicar efetivamente recursos para atingir um objetivo, ou ainda, no dizer de Sparling: ... a disposição das diversas partes de um todo em um organismo". (7) (Os grifos não são do original).

Outros autores também, definiram a Organização, numa multiplicidade impressionante de interpretações que nem sempre conduzem o estudante a um só fim. HENRY FAYOL, por exemplo, considera a Organização uma função, e O. SHELDom a entende um processo, enquanto SPRIEGEL e LANSBURGH interpretam-na uma relação estrutural, e L. URWICK, a determinação de atividades. (8)

Para finalizar êste capítulo, gostariamos de incluir um só têrmo: programação.

Êsse têrmo vem sendo utilizado com o mesmo significado de "planejamento". Entendemos que "programar" não implica, obri gatòriamente, uma necessidade criadora e nem diz como fazer as
coisas. A programação pode relacionar, ainda que mentalmente,

(4) Curso de Organizasão do Trabalho - C. Cantanhede, pág. 15.
(5) Ibidem, pág. 17.

(6) Ibidem, pág. 17

(7) Ibidem, pág. 18

(7) Curso de Organizą̧̃o do Trabalho - C. Cantanhede, pág. 15.

(8) Definições de Organização enunciadas pelos citados autores. 
fatos, circunstâncias, ou elementos de alguma coisa que já foi ou não planejada. Programação implicaria, dessa forma, a existência ou não de um planejamento anterior. Planejar, por sua vez, já é função de uma necessidade criadora, ainda que não essencialmente inovadora. Implica uma necessidade pesquisadora e o conhecimento do que, por que, como, por quem, e onde as coisas devem ser feitas e o que fazer para que tal aconteça. Implica, ainda, um arranjo e combinação de diferentes recursos, no sentido de se obter a melhor mistura para a solução do problema e, finalmente, uma autocapacidade de admitir a relatividade em tudo quanto foi levantado, analisado, criticado e sugerido.

\section{A relatividade no planejamento}

Planejar implica a necessidade de dotar o organismo de recursos mentais, materiais e energéticos que o tornem capaz de produzir um benefício máximo e global. Implica, por isso mesmo, a resolução de múltiplos problemas de um organismo e a capacidade de admitir certa relatividade naquilo que foi levantado, analisado, criticado e sugerido.

A mente humana possui reservas inesgotáveis de uma energia que hoje admitimos gravitar no cosmos. Atraindo e modificando essa energia, o homem pode projetá-la de volta ao cosmos, numa garantia a seu próprio equilibrio. No seu permanente evolver, êle admite a necessidade de sistematizar todo o processo organizacional, para que os objetivos de maior confôrto, maior proteção melhor e mais ampla justiça sejam atingidos com maior segurança e dentro de limites razoáveis de tempo. Hoje êle está certo de que sòmente a simples associação humana não é o bastante para atingir êsses objetivos. Partem do pressuposto de que tôdas as formas de associação humana sòmente conseguiram obter um minimo de benefícios sociais simplesmente porque não voltaram, ainda, a devida atenção para a técnica do planejamento, única forma coerente de atender ao crescente acúmulo e complexidade das necessidades humanas. O reconhecimento a uma necessidade planejadora cria nova mentalidade e possibilita a maximização de interêsses e desejos dentro de um grupamento humano. Mas como se comportariam os elementos estruturais de um organismo humano quando se faz incidir sôbre êles alguma coisa planejada? Examinemos alguns dêsses elementos à luz da relatividade.

\section{A relatividade na estruturação do organismo}

Em Organização costumamos interpretar a estrutura de um organismo segundo sua parte materializável, isto é, a que lhe dá corpo. Evidentemente, se materializamos um organismo, estamos 
admitindo a existência nêle de partículas infra-estruturas que se inter-relacionam na formação de um todo. Se essas partículas se compatibilizam entre si, o todo funciona e vive.

Tôda forma de organização humana tem muito que ver com os padrões instituidos pelo homem, numa tentativa de compatibilizar os elementos que ali existem. Essa busca à compatibilização, ao equilbrio estrutural, é ditada pela experiência acumulada em várias gerações e pela necessidade que o homem sente de criar, instituir e fazer.

Ao mentalizar uma forma o homem procura dotá-lo de recursos mentais, materiais e energéticos capazes de permitir ao organismo um satisfatório funcionamento. Assim, êle tem procurado reunir, tanto quanto lhe permitem o conhecimento e a experiência, todos os elementos infra-estruturais que se identificam com o organismo que imaginou. Na sua ânsia de realizar uma obra perfeita, êle penetra profundamente no campo da sua imaginação, buscando identificar os elementos mais compativeis com a estrutura que pretende ver funcionando. - Sưa primeira preocupação é, portanto, a identificação dêsses elementos.

E' bem verdade que $1 \mathrm{~m}$ conceito de "estrutura" não diz sò mente com a identificação e reunião de seus elementos infraestruturais. Há, por certo, condicionantes que limitam as ações do homem a qualquer tentativa de construção de um modêlo perfeito. Quando instituiu o quadro estrutural, o homem deu ao organismo um caráter meramente formal. Tudo ocorreu como se, ao montar um quebra-cabeças, êle já tivesse, prèviamente, limitado a quantidade e qualidade das peças que solucionariam o problema. T'udo dependeu, portanto, dos limites da sua fôrça mental, isto é, da sua profundidade de imaginação. A fim de tornar substancialmente utilitária essa fôrça mental, êle procurou não introduzir certos elementos na composição do mosaico estrutural, atento à evidência de que uma tentativa nesse sentido poderia deflagrar um movimento endógeno mediante o qual as parcelas infra-estruturais do sistema hão de buscar novos perfis de equilibrio, mais compativeis com o todo que desejam expressar. Assim, a má colocação de uma peça ou a sua evidente incompatibilização com o sistema estrutural, não há de permitir a correta formação da estrutura. Poderia ocorrer, quando muito, a dinamização dessa estrutura, sem que necessàriamente ocorresse sua evolução. Nesse caso, a subversão dos elementos infra-estruturais na busca de um perfil de equilibrio provocaria a luta, por vêzes desigual, entre os elementos que integram o organismo.

O problema da contemporaneidade dos elementos infra-estruturais seria outro fator condicionante a qualquer tentativa de construção de um modêlo perfeito. Um organismo vivo procura 
revitalizar permanentemente suas células, mediante eliminação de substâncias que lhe são nocivas e absorção de outras que lhe são benéficas e que lhe permitem melhor e mais cômodo funcionamento. Assim ocorre, também, com a estrutura de qualquer organismo instituido pelo homem. Seu funcionamento em bases razoáveis vai depender da contemporaneidade de seus elementos. Não se impõe aqui, a eliminação dos elementos mais antigos, mas sòmente daqueles que constituem uma sobrecarga para o organismo e que prejudicam ou limitam os seus objetivos e, ainda, que o tornam inútil.

Do que foi dito identificamos três problemas relacionados a uma razoável definição de "estrutura":

- o da identificação e possibilidade de reunião de seus elementos infra-estruturais;

- o da não introdução de um elemento que possa incompatibilizar se com os demais na estrutura;

- o da contemporaneidade dos elementos infra-estruturais.

E' de um artigo da série "Textos Selecionados" - Parte $\mathrm{V}$ (9) o seguinte trecho:

"Uma vez que os programas estão sempre modificando-se (sic) e que o volume nunca permanece constante, os problemas de organização não encontram nunca uma solução final. Nenhuma estrutura pode ser permanente em todos os aspectos, e deve sofrcr modificações sempre que necessário". (O grifo não é do original).

Celso M. Furtado, em um artigo publicado em 1946 na Revista do Serviço Público, dá-nos certos fatôres determinantes na variação das estruturas, quando observa:

" $E$ ' natural que não havendo duas situações históricas idênticas, nem dois conjuntos idênticos de circunsâncias, - não haja, também, duas organizações idênticas". (10) (O grifo não é do original).

$\mathrm{O}$ autor simplesmente não se preocupou em relacionar os elementos que deveriam integrar a estrutura, certo de que um esfôrço nesse sentido ser-lhe-ia inútil.

RenNé. Dèscartes, numa tentativa despretensiosa, parece-nos dar a chave para resolução de diferentes problemas. Seus quatro

(9) Revista do Serviço Público, vol. 1, n 2 - fevereiro de 1946 , pág. 17.

(10) Celso M. Furtado - Revista do Serviço Público - fevereiro de 1946, pág. 17 . 
preceitos constituem até hoje uma norma à pesquisa científica. Seria permitido a nós, contudo, a aplicação integral do segundo preceito?

\section{Assim nos fala Dèscartes:}

"Dividir cada uma das dificuldades que houvesse de examinar em tantas parcelas quantas pudessem ser e fôssem exigidas para resolvê-las melhor". (11)

A resposta deve ser meditada. Quando muito seriam permitidas ao homem as divisões parciais, porque no conceito de absoluto entendemos o infinitamente grande $e \quad o$ infinitamente pequeno, também.

Simon, Smithburch e Thompson observam a questão estrutural dos organismos, e concluem:

"Cabe ao analista de organização identificar os possiveis métodos de especialização e confrontar uns com os outros, para avaliar as respectivas vantagens e desvantagens. A sobrevivência da organização pode depender da exatidão dessa avaliação".

Anderson e Schenning dão-nos uma prova da relatividade no planejamento da estrutura de um organismo quando dizem:

"A estrutura da organização ou o arranjo e relações de trabalhadores e encarregados executivos entre si e com o todo, como uma unidade orgânica, é determinada pelo trabalho a ser feito, pelo equipamento e facilidades de fazê-lo, e por certas leis psicológicas e princípios gerais de conduta humana. (13)

$\mathrm{Na}$ escolha do tipo estrutura que mais convém ao organismo, nossos autores são unânimes em aceitar a tese de que a estrutura deve ser:

“- simples, quanto à disposição hierárquica; definida, quanto à divisão de funções; e unificada, quanto à coordenação das funções". (14)

(11) Renné Dèscartes - citado po: C. Cantanhfide no Curso de Organização do Trabalho. pảg. 21.

(12) Simon, Smithrurgh e Thompson - citados por Beatriz Wahrlich em seus "Cadernos de Admin'stração Pública", n 42 - pág. 66.

(13) Anderson e Schenning - pág. 110.

(14) Textos Selecionados - Parta V, E.B.A.P. - pág. 69. 
Os tipos estruturais criados pelo homem são, contudo, meramente convencionais e, por isso mesmo, transitórios, variando em função do espaço, do tempo e dos recursos existentes.

"Daqui se infere, fàcilmente, que a estrutura não é imutável. Estabilidade de estrutura pode ser um mau sintoma; nada, entretanto, indica que seja bom". (15)

Nenhuma estrutura pode ser considerada tão perfeita no universo que se adapte a tôdas as situações em todos os momentos, e a que não evolui tende a desaparecer.

“... a teoria da estrutura só se torna realmente fecunda se se tem em vista os aspectos dinâmicos da organização". (16)

Condicionados são, assim, todos os tipos estruturais criados pelo homem. Eles se amoldam, evidentemente, às circunstâncias, aos fatos, ao tempo e espaço e aos recursos disponiveis, mas não lhes é permitida a capacidade de se tornarem absolutamente contemporâneos e coerentes em tôdas as situações.

\section{A relatividade na seleção de recursos}

Já falamos várias vêzes em recursos mentais, materiais e energéticos que gravitam dentro dos organismos instituídos pelo homem. A seleção dêsses recursos constitui um dos mais sérios problemas na técnica do planejamento.

O primeiro aspecto a considerar seria o da identificação dos diferentes recursos capazes de solucionar o problema. Nem sempre isso é possivel, simplesmente porque ainda desconhecemos a existência de muitos recursos ou não tivemos a capacidade de estabelecer uma relação entre êles e o problema que tentamos solucionar.

Os recursos são selecionados dentro da limitada faixa do conhecimento humano, mas a despeito disso, êles podem contribuir para a formação de numerosas soluções alternativas. Algumas dessas soluções apresentar-se-ão mais compativeis do que outras, sem que a escolha final recaia, necessàriamente, sôbre a que possua os melhores predicados. Queremos dizer que nem sempre nos é permitida a obtenção daquilo que sabemos existir e para o qual já estabelecemos relações de identidade com o pro-

(15) Celso Furtado - Revista do Serviģo Público - fevereiro de 1946, pág. 17 .

(16) Ibidem, pág. 17. 
blema. Sendo assim, vive o homem sempre na função direta de suas capacidades.

\section{A relatividade nos recursos humanos}

Dentre os recursos a selecionar, o relativamente ligado à mente constitui, sem dúvida alguma, o mais importante. E' bem verảade que já se instituem organismos com a mínima participação do homem no seu processo de funcionamento, em centros onde a automatização atingiu níveis bem elevados. Isto não quer dizer, porém, que na seleção de recursos para êsses organismos, não se tenha considerado a fôrça mental das pessoas.

Sabemos que o homem, na sua estrutura complexa, reage de diferentes formas a diferentes estimulos. Os "mecanicistas" e "anatomistas" da Organização foram veementemente criticados pelos membros das escolas sucessoras, justamente porque não consideraram o homem como ser que se comporta segundo raizes sociológicas e de acôrdo com sua estrutura psicológica.

Dar o lugar certo ao homem certo é um conceito tradicional muito relativo, assim como a formação de uma equipe profissio'nalmente coesa, já não é mais o caráter predominate. E' indispensável a compreensão de que é no local de trabalho que o homem passa a maior parte do seu tempo, e é ali que procura estabelecer relações com os demais membros, numa tentativa de buscar algo mais que uma retribuição simplesmente pecuniária.

"Qualquer fracasso na escolha e adaptação do pessoal terá sérias conseqüências - para o trabalhador: a má adaptação, o descontentamento, a frustração e o risco de acidentes; para a emprêsa: a queda de produção, a perda de valores humanos e a instabilidade do pessoal". (17)

Esforços já têm sido feitos no sentido de identificar o organismo como algo mais do que a simples estratificação de matérias que se inter-relacionam e se harmonizam para fins puramente econômicos.

"Uma organização industrial vem a ser mais do que uma multiplicidade de individuos agindo, apenas, em relação a seus interêsses econômicos". (18)

(17) Revista de Organização e Produtividade, do I.D.O.R.T. - setembro e outubro de 1960 , pág. 9 .

(18) Roethlisberger - Managcment and Morale, pág. 59. 
A identificação de uma alma grupal nos organismos, onde dezenas, centenas e milhares de almas elementares pudessem tentar um processo de interação, possibilitaria, sem dúvida, a obtenção de imprevisiveis benefícios.

Seria possivel, contudo, uma orientação seletiva que considerasse, também, a "anima" do individuo?

Parece-nos que no apêlo às massas está o primeiro problema. Comumente nos dirigimos a determinadas pessoas, e mais precisamente, àquelas que possuem a formação profissional exigida. Uma vez selecionadas, elas se incorporam ao organismo no pressuposto de que vivam nêle e com êle também. E' sempre difícil a previsão, todavia, de que venham a sintonizar com os membros ali já existentes. Nem sempre um comportamento é condição suficiente de sintonia. Há certas manifestações da alma que chegam a ser imperceptiveis ao homem desprevenido e que não se traduzem como possam transparecer.

\section{A relatividade nos recursos materiais}

a) Instrumental - Dos recursos materiais o instrumental sofre, também, as influências de certos fatôres que precisamos considerar. Dêsses condicionantes, exerce eșpecial influência o tempo de vida útil do bem.

À medida que vai sendo utilizado na produção de bens ou de serviços, o instrumental vai sofrendo um processo de desgaste, uns mais lentos que outros, contribuindo assim, para um rendimento decrescente na produção. Êsse desgaste pode ser causado por uma série de fatôres: imprevidência na sua manutenção, operação defeituosa, atrito de peças, operação incompativel com a finalidade para a qual foi criado o instrumental e outras formas de manifestação. Mesmo quando a manutenção é satisfatória do ponto-de-vista técnico da operação, o rendimento do instrumental não é o mesmo em tôdas as situações. Evidentemente, o contrôle da qualidade estabelece certos limites para aprovação do prcduto final, não desconhecendo a relatividade que existe no uso de um equipamento e, mesmo, no material de que é feito o produto. For outro lado, a substituição de peças do equipamento em épocas oportunas ou a simples reparação ou calibragem do instrumental são fatos suficientes para demonstrar a relativa aplicação do equipamento. Não só vai ocorrer a desigualdade nas peças, como também, as calibrações vão depender muito da capacidade de aferição do operador, no momento, e bem assim, dos instrumentos de que se vai utilizar para atingir tal fim.

$\mathrm{O}$ equipamento não executa seus movimentos sem a mínima intervenção do homem, por menor que seja a sua atuação no 
processo produtivo. Assim sendo, mudanças de ordem psicológica ou fisiológica no homem podem alterar o processo de operação das máquinas várias vêzes por dia, impossibilitando um caráter de uniformidade no serviço que prestam.

Um outro aspecto a considerar no equipamento é a preocupação do homem em transmitir à máquina tarefas mais pesadas e mais complexas até certo ponto, e que executadas de outra forma lhe seriam onerosas ou demoradas. Tendo sido imaginada e criada pelo homem, a máquina procura desempenhar bem o serviço de que lhe incumbiram, principalmente porque não sofre certas influências perturbadoras decorrentes de fenômenos fisiológicos e psíquicos. Naquela preocupação, êle não conseguiu dotar a máquina, ainda, de um cérebro que pudesse, simultâneamente, pensar, agir e concluir, se não estiver preparada para isso. Quem comanda o inicio de seu funcionamento é o homem; quem elabora o "programa" de processamento é também, o homem. Se o comando é emitido erradamente, ou se a "programação" sofre as influências de uma indisposição orgânica no homem, e não atende o objetivo desejado, a máquina não vai discutir com êle. Falta-lhe essa capacidade, e ela processa aquilo que the ordenaram, exclusivamente.

Finalmente, todo equipamento funciona com certo rendimento, aceitável, se é operado por especialistas. O rendimento da máquina tem muito que ver com essa condição. Nem tôdas as máquinas foram construídas para serem utilizadas por qualquer pessoa, assim como não o foram para qualquer serviço. Não seria ilícito afirmar, portanto, que o homem certo deveria operar a máquina certa. Aquêle que se deixa governar pela máquina naturalmente se torna com ela incompativel, e não produz aquilo que é de se esperar. Não se trata de buscar super-homens no manejo de instrumentos, mas ter a capacidade de arregimentar, selecionar, treinar e assistir os que apresentem maiores possibilidades de fazer sistema com êles. Estamos convencidos de que assim pensaram TAYLOR e os demais mecanicistas quando estabeleceram o sistema "homem máquina".

b) Material - No emprêgo do material, a teoria da relatividade se manifesta desde a sua aquisição. Encontramos essa primeira manifestação na escolha das propriedades que deve possuir o material adquirido. Nem sempre as conclusões partem de um laboratório especializado, mas isso não afeta absolutamente, - que desejamos apontar. De qualquer forma é importante para o nosso trabalho lembrar que os materiais escolhidos devem possuir certas propriedades, sem o que não vão atender às exigências do produto acabado ou do serviço realizado. Uma vez sele- 
cionados, os materiais são empregados sob determinadas condições, dentre as quais:

- oportunidade de aquisição - um material pode não estar, momentâneamente, à disposição da emprêsa que dêle necessita, por motivos de tôda sorte: creditícios, inexistência episódica, problemas de transporte, de armazenagem, etc.

- contemporaneidade de utilização - embora escolhido por abranger a totalidade das propriedades exigidas, um material pode não estar, ainda momentâneamente, interessando à emprêsa, em virtude de uma eventual paralisação de parte da sua produção, quer por falta de mercado, como por deficiência do instrumental ou falta de pessoal especializado que o possa manipular.

$E^{\prime}$ fácil depreender que o tempo está ìntimamente ligado à utilização do material, da mesma forma que para o instrumental. De fato, êle vai determinar quase sempre o emprêgo ou não dêsse ou daquele material, ainda que um dêles se apresente mais adequado à qualidade do produto, em função das especificações de engenharia.

A utilização dos materiais se condiciona, finalmente, a determinados fatôres de estimativa da produção. Quando se compromete com os clientes, o órgãos comercial da emprêsa está pràticamente emitindo um comando para funcionamento das linhas do setor industrial. As fábricas não produzem à sua revelia, mas em obediência a um programa de vendas, geralmente estimado para determinado periodo de tempo. Assim, o gerente industrial procura atender a essa programação, estimando uma outra, segundo os recursos de que sabe dispor no momento, ou que tem a capacidade de incorporar durante aquêle periodo de tempo fornecido pelo gerente comercial. Quer se trate de produção por empreitada ou de produção normal da emprêsa, descontinua ou não, o gerente industrial impõe uma obediência às misturas de material, prèviamente organizadas por setor técnico. Considerando que deve haver um estoque suficiente para cobrir o periodo estimado, o gerente industrial procura dosar êsse material e providenciar sua reposição o mais breve possivel, desde que necessário. De uma forma ou de outra êle quer atender à programação e evitar, tanto quanto possivel, os prejuizos que lhe possam ser debitados. Essas dosagens são, todavia, estimadas, isto é, pressupõe-se que os elementos de cálculo sejam o bastante para disciplinar o consumo dos diferentes materiais de que a produção vai necessitar para atender a uma quantidade $x$ de produtos. Não fôsse a participação do homem e mesmo das máquinas no processo produtivo, 
admitiríamos por exata essa suposição. Os estragos com a má aplicação dos materiais e bem assim, o descaso pelas coisas alheias, têm sido, entretanto, uma das causas também de elevação dos custos fabris.

A relatividade no planejamento de rotinas, de métodos e sistemas

A validade dos respectivos conteúdos seria a nossa preocupação nesse aspecto do planejamento, em função do espaço e do tempo de existência dêles.

O planejador não procura dar à rotina, ao método e ao sistema fôrças de leis absolutas, mas ao instituí-los, admite um prazo de validade, dentro do qual, o comportamento dos diferentes elementos pode ser constante. A partir do momento em que o envolver dinamizador das estrutura força os elementos do organismo à tomada de uma nova posição, as rotinas, os métodos e os sistemas planejados deixam de ser compativeis com a situação atual, isto é, tornam-se inapropriados para o organismo e seus objetivos. E' certo que a introdução de um novo elemento pode modificar a rotina, o método e o sistema, ainda que não simultâneamente, os três.

E' admissivel pressupor que o método ou o sistema não seja atingido pela alteração da rotina, e mesmo que a modificação do método não abale o sistema; mas a todo desequilibrio de um sistema ocorrerão fatalmente alterações, ainda que não substanciais, nas estruturas básicas do organismo.

A implantação de um sistema de contrôle mecanizado, por exemplo, modifica o panorama estrutural, que recebe agora, um órgão de características bem definidas. Não se trata de simples substituição de um setor por outro, mas da introdução de um elemento que se torna contemporâneo com as necessidades da emprêsa. Poder-se-ia concluir, e geralmente assim é, pela inadequação de uma parte do setor reestruturado, mas sempre ocorrerá o aproveitamento dos elementos considerados compatíveis com o novo sistema.

A modificação do sistema pode não afetar a rotina, nem há de modificar na sua essência o método empregado. Em uma organização de produção êsse fato sói acontecer freqüientemente. No exemplo acima, o método empregado pode ser ou não totalmente modificado, isto é, a mecanização não elimina ou elimina o método manual, sendo muito comum a combinação dos dois. As rotinas também podem ou não ser ajustadas ao novo sistema sem prejuizo de sua essência fundamental.

Outra característica que prova a relatividade no planejamento de uma rotina, de um método ou de um sistema é a sua maior ou 
menor capacidade de resistir às mudanças de situações, sem prejudicar o bom funcionamento dos serviços. Por mais flexíveis que sejam hão de oferecer sempre um ponto vulnerável, que, uma vez atingido, sòmente poderá ser restaurado pela iniciativa do homem. Podemos prever várias situações e indicar o melhor modo de contornar as irregularidades, mas sempre ocorrerão outras tantas para as quais pode ou não existir um remédio, dependendo das condições apresentadas no momento; e sòmente a experiência do homem poderia contribuir para a volta à normalidade.

Finalmente, tôda emprêsa merece um estudo especial dos seus problemas. Não há duas situações idênticas nem dois métodos e duas rotinas também. Seria lícito supor o aproveitamento dos mais reconhecidos como base de estudo e planejamento específicos.

Existem vários sistemas mecanizados, mas nem tôda emprêsa pode usá-los indistintamente. Já nos referimos à validade de considerar a máquina certa para o homem certo e entendemos que o homem não deve ser subordinado a ela. Sendo assim, a imposição de um certo sistema mecanizado pode modificar profundamente a estrutura de pessoal e gerar uma desarmonia de graves conseqüências. E' fundamental considerar que os padrões criados no planejamento de rotinas, métodos e sistemas são meros orientadores de um planejamento específico.

\section{A relatividade na determinação de padrões de desempenho}

Não vamos discutir nem apresentar as situações em que o organizador poderia determinar e aplicar padrões de desesmpenho. Estariamos fugindo dos objetivos dêste despretensioso trabalho se assim fizéssemos. Gostariamos de apontar, isto sim, onde existe a relatividade.

Dentre os elementos de contrôle das gestões, os padrões de desempenho ocupam, sem dúvida alguma, lugar de destaque, tal é a contribuição que podem emprestar a um satisfatório funcionamento do organismo. Seu campo de aplicação, contudo, tem sido limitado, mesmo nas emprêsas de produção, por fôrça de sua própria relatividade.

Entendemos que os padrões de desempenho foram criados para medir a eficiência de uma operação, tarefa ou grupo delas, em função de certos fatôres que atuam dentro do quadro real. Mas o que pode ser considerado eficiência no organismo particular já não terá, necessàriamente, o mesmo significado no organismo público. Assim, os resultados de um padrão estabelecido para medir a eficiência de uma operação, tarefa ou grupo delas podem ser interpretados de diferentes maneiras, e o que pode 
ser considerado satisfatório para um, não será, necessàriamente, para outro.

Um padrão de desempenho estabelecido para um setor qualquer da administração pública tem por objetivo primário a satisfação das necessidades públicas atendidas por êsse setor, não importando aí o aspecto econômico do resultado aferido. $\mathrm{Na}$ emprêsa particular, todavia, o resultado econômico e financeiro do empreendimento é uma constante preocupação.

$\mathrm{Na}$ determinação de padrões de desempenho a preocupação dos técnicos teria sido dirigida para a melhor maneira de controlar tudo aquilo que dissesse respeito ao organismo, não fôsse a existência de certas limitações de ordem não técnica. Nas organizações de produção, principalmente, tem ocorrido uma tendência muito acentuada para limitar o problema aos campos de aplicação exclusivamente técnicos. Essa limitação decorre do fato de que o desdobramento das operações é bem mais fácil, permitindo sua análise em bases mais razoáveis de exatidão. A solução do problema é, assim, centralizada no que diz respeito à produção dos bens e dos serviços, sòmente.

Um importante atributo dos padrões de desempenho é o caráter de uniformidade que devem emprestar ao contrôle de uma operação, tarefa ou grupo delas. Quando atribuem um padrão de desempenho, os técnicos costumam considerar todos os elementos capazes de tomar uma forma matemática, na qual o fator tempo é uma constante. Não lhes sendo permitida a construção de um modêlo perfeito, êles se preocupam mais com a maior ou menor possibilidade de aferição e, por êsse motivo, abandonam certos fatôres que por sua natureza complexa não contribuem para êsse fim. Dessa forma, naturalmente deixam de incluir no modêlo todos os fatôres de ordem fisiológica (com exceção, talvez, da fadiga) e, muito particularmente, os de ordem psicológica, de difícil uniformização.

Mesmo nas operações mais simples, essa relatividade costuma desviar de quando em quando os padrões mais resistentes e mais supostamente exatos. Desvios constatados em operações muito simples podem ser considerados despreziveis, se apreciarmos essas operações isoladamente. Se, todavia, observarmos o comportamento delas em conjunto, é possivel que os desvios elementares já não mais o sejam, tendo em vista a participação de um complexo maior de fatôres.

Outro aspecto a considerar, ainda, seria aquêle que não permite aos elementos de um padrão de desempenho um comportamento ideal em tôdas as situações semelhantes. O padrão sofre, permanentemente, a influência dos elementos reais que deve aferir, 
sendo por êle forçado a periódicos reajustamentos. Não seria ilicito admitir, na realidade, uma inversão de posições. Tendo por finalidade aferir o comportamento dos elementos reais, o padrão acaba sendo aferido quando se dá início à operação.

Um padrão de desempenho pode ser útil na aferição do comportamento de um quadro real, mas seria demais admitir igual eficiência em quadros semelhantes, situados ainda que no mesmo setor do organismo. Tanto quanto possivel, poder-se-ia estabelecer uma identidade entre dois quadros reais, e utilizar o padrão de um como base para a determinação do padrão de outro.

Em muitos casos, também, é possivel estabelecer dois ou mais padrões de desempenho para uma só operação, tarefa ou grupo delas, atendendo a duas ou mais situações. Êsses tipos de padrões costumam dar muita flexibilidade ao processo de aferição porque permitem levar-se em conta a situação predominante no momento. Evidentemente, não se vão estabelecer tantos padrões quantas sejam as situações que possam ocorrer. Essa é, também, uma condição imposta pela relatividade, sem dúvida alguma.

Outra preocupação dos técnicos em organização tem sido aquela que visa à contemporaneidade dos elementos formadores de um padrão de desempenho. No todo, o setor que não funciona deve ser atualizado pela eliminação das partes que constituem uma sobrecarga para si, e introdução de outras que permitam o seu coerente funcionamento. Sendo assim, os padrões de desempenho devem ser permanentemente testados, para que os resultados não sejam distorcidos.

Desvios maiores ou menores do que os limites fixados constituem excelentes instrumentos de contrôle da contemporaneidade do padrão fixado. Tornar contemporâneos os elementos de um padrão é, todavia, impraticável. O técnico poderá imaginar um padrão de certas possibilidades que, aplicado sob determinadas circunstâncias, dê um resultado satisfatório, mas qualquer tentativa de atualizar um padrão há de resultar infrutifera. Entendemos que o homem pode atualizar seus conhecimentos, mediante incorporação de novos assuntos, sem que isso represente, obrigatòriamente, uma eliminação dos conhecimentos já adquiridos e incorporados. Tanto quanto possivel, êle há de reservar para ocasião mais oportuna a experiência que já retém, mas não estar belece uma condição de permuta quando tem oportunidade de assimilar novos conhecimentos. Nem por êsse motivo ser-lhe-iam negadas as possibilidades de se tornar contemporâneo. Os elementos de um padrão de desempenho, contudo, submetem-se àquela condição de permuta. Suponhamos que, para tornar uma operação mais simples e econômica, os projetistas de órgão de engenharia alterem o desenho de uma ferramenta especial qual- 
quer. O operário, antes acostumado a uma operação mais rigorosa, há de ver aumentada sua produção pela comodidade que agora o novo trabalho oferece. Evidentemente, o padrão antes estabelecido já não mais reflete o quadro real. Parece-nos lícito afirmar que, na verdade, ocorreu a substituição ou a permuta de um padrão por outro, e não a atualização do padrão anterior.

Acreditamos que os exemplos apontados sejam o suficiente para justificar a relatividade que existe na determinação e na aplicação de padrões de desempenho.

\section{A relatividade na tomada de decisões}

O que leva o homem a decidir?

"Se há alguma esfera da atividade administrativa que permanece em terra incógnita é, provàvelmente, a da tomada de decisões". (19)

As decisões constituem uma forma de manifestação da vontade humana, naturalmente influenciada, tanto quanto possivel, pela razão. E' através da mente que os homens procuram identificar as soluções para seus problemas.

Nas emprêsas, as decisões, realmente, dinamizam as atividades e podem ou nãu contribuir para o seu coerente funcionamento. Dinamizar não corresponde, necessàriamente, a uma evolução e, dessa forma, nem tôdas as decisões contribuem para tal fim. Seria insuficiente justificar a tomada de uma decisão pela identificação dos elementos de um problema. E' preciso ter a capacidade de aliciar várias soluções e, o que é mais importante, dar início a um processo de eliminação das que se incompatibilizam não com o problema em si, mas com os desígnios da emprêsa, e daquelas, também, que embora se compatibilizem estejam momentâneamente fora de cogitações, quer pela sua incontemporaneidade, quer pela impossibilidade de serem adotadas por falta de recursos. Saber avaliar o que realmente interessa no momento não é tarefa das mais fáceis. As circunstâncias e os fatos, muitas vêzes, alteram profundamente a decisão original, a menos que se estabeleça uma eficaz coordenação.

Suponhamos que o diretor-gerente de uma emprêsa, para agradar a um seu cliente, comprometa-se a fornecer, dentro de cinco dias, mil caixas do produto $x$, sem uma consulta prévia ao setor de vendas. Imediatamente êle solicita abertura de crédito nas condições normais de transação com aquêle cliente, e obtém a

(19) Kubli, Harold - Advanced Management - Junho de 1953. 
confirmação desejada. Duas decisões apenas, de nosso diretorgerente, poderiam acarretar o seguinte:

- o pedido e o fornecimento são normalmente processados, a despeito da falta de consulta ao setor de vendas;

— embora mereça crédito - já concedido, aliás —, o pedido fica suspenso temporàriamente por falta de estoque em quantidade suficiente, tendo em vista que o cliente não deseja recebimentos parcelados.

No primeiro caso, os efeitos da decisão não constituem um problema, mas no último, nosso diretor-gerente teria que decidir:

- pela suspensão temporária do fornecimento;

- pela redução do limite de crédito do cliente ao nível existente no estoque;

- pela compra ou fabricação urgente da quantidade de produto $x$ que complementasse o pedido original.

Evidentemente as duas primeiras soluções, embora possiveis, não se compatibilizariam com os desígnios da emprêsa, que goza de boa reputação no mercado e não quer deixar em falta seus clientes. A última solução, portanto, seria a escolhida. Mas a decisão de fazer ou comprar não é das mais fáceis para nossa emprêsa, que se dedica à industrialização do produto solicitado.

Em nosso caso, a hipótese de comprar o produto para revenda foi eliminada, ficando sòmente a solução de fabricá-lo. O gerente industrial prometeu estudar o assunto e dar uma resposta para o mesmo dia, enquanto nosso diretor-gerente tranqüilizava o cliente.

As matérias-primas utilizadas na fabricação do produto $x$ haviam sido consideradas obsoletas pelo contrôle da qualidade em suas últimas informações à engenharia de fabricação, e o gerente industrial, mesmo assim, não garantia uma quantidade suficiente para atender totalmente o pedido. Por outro lado, os instrumentais teriam que ser adaptados, o que talvez exigisse uma complementação de mão-de-obra direta para acelerar o processo de fabricação tão logo as máquinas estivessem à disposição.

O exemplo acima, embora possa transparecer o de uma emprêsa desorganizada é, na realidade, um caso a mais na tomada de decisões a preocupar os dirigentes de emprêsas. A despeito de todos os esforços no sentido de disciplinar as decisões, elas sempre se apresentarão com algo de relativo, simplesmente porque emanam do homem. Se êle trabalha sòzinho, os efeitos daquilo que executa podem refletir a sua decisão original, mas se trabalha em grupo - e estamos supondo que assim seja -, as conse- 
qüências de uma decisão poderão estar em completo desacôrdo com o pensamento original ou, se assim não fôr, estar, pelo menos, incontemporâneas com o problema.

Não precisamos encerrar a história do nosso diretor-gerente. $E^{\prime}$ evidente que êle não vai conseguir do seu gerente industrial a quantidade de produto $x$ para a qual assumiu um compromisso dentro de cinco dias.

\section{A relatividade na chefia}

E' de Henry Fayol um estudo sôbre as capacidades. Êle o introduziu em sua obra sob o título "Importância relativa das diversas capacidades..." (20)

Esse estudo é particularmente interessante para o nosso trabalho, que é o de apontar, justamente, as relatividades na Organização. Eis um trecho do capítulo:

"Convém notar que não se trata aqui de comparar o valor de um operário com o de um contramestre, de um diretor ou de um chefe de Estado. Não há medida comum entre êsses valores... Não tratei de expressar nos quadros nò 1 a 5 , se não, a importância relativa das diversas capacidades de um agente". (21) (O grifo é nosso).

Evidentemente, não cabe nesse trabalho discutir a validade dos resultados obtidos por FAYOL, mas observar sua preocupação em dosar, sob a forma de números relativos, as diferentes capacidades de um "agente". Êle fêz questão de deixar bem clara essa posição no seguinte trecho:

"Esse valor total é representado em todos os casos, para um agente perfeito, por 100, quer se trate de um operário, de chefe de serviço ou de chefe de Estado". (22) (O grifo é nosso).

De todos os aspectos ligados à chefia, os psicológicos encerram tôda uma relatividade. Dotados que são de raciocínio, os homens podem conseguir um relativo equilibrio do grupo a que pertencem, especialmente se voltam suas atenções para uma idéia predominante. O chefe pode tentar uma relativa coesão do grupo que dirige, se consegue mantê-lo voltado para seus

(20) HenRY FAYOL - Administrasão Industrial e Geral - pág. 13.

(21) Ibidem - pág. 15.

(22) Ibidem - pág. 15. 
interêsses comuns. Dificilmente conseguiria de outra forma, porque os homens nunca agem sem um fim pré-determinado, individual por excelência, e que os encoraja à luta. (Omnes agens agit propter finem - ARISTóteI.ES).

De modo menos seguro pode o chefe relacionar um grupo a têrmos profissionais, se as capacidades que tem de liderança estiverem calcadas em qualidades técnicas, intelectuais e morais. Em princípio, qualquer tentativa de relacionar êsse grupo a sentimentos, deve admitir uma grande relatividade. Roethlisberger, por exemplo, observa que os sentimentos:

“... não podem ser modificados apenas, em função de lógica. Agem em nosso pensamento como um sistema de verdades absolutas". (23)

\section{A relatividade no custo fabril}

Entendemos que é necessário valermo-nos de todos os recursos disponíveis se desejamos organizar alguma coisa. Assim compreendemos a posição do organizador, como profissional capaz de reconhecer dentro de uma emprêsa-padrão, todos os seus aspectos gerais.

Existe hoje uma acentuada tendência para a criação de uma contadoria de custos nas emprêsas. E' preciso entender que a técnica de formação dos custos transcende qualquer noção simplista de tabulação matemática. Necessário se torna o reconhecimento de uma "conduta" nas equipes, voltada para algo mais do que isso.

O contador de custos atualmente não está mais subordinado ao órgão de contabilidade geral e procede mesmo com certa influência sôbre aquêle setor de contrôle. Nem todos os registros da contadoria de custos estão vinculados aos que a contabilidade geral efetua e podem mesmo servir de instrumento capaz de alterar substancialmente certos dados ali registrados. Tudo vai depender do comportamento dos fatôres da produção, em face das previsões e estimativas elaboradas e, bem assim, da politica empresarial no que respeita aos custos.

Em custos existe um critério próprio de apuração segundo a finalidade de utilização. Se o objetivo diz respeito à "comercial", o critério tem em vista, principalmente, a politica de preços; se é conduzido para uma redução de custos, dirá certamente, respeito à "industrial"; se tem em vista corrigir os efeitos favoráveis ou desfavoráveis para determinado periodo, resultantes das variações de custo ocorridas em material, mão-de-obra e despesas indiretas

(23) Roethlisberger - Management and Morale - pág. 31/32. 
de fabricação, o agente interessado há de ser a "financeira". Se, por outro lado, tiver por objetivo mostrar a maior ou menor incorporação de fatôres nacionais ao produto acabado, o critério há de se basear na politica de favores fiscais; se, finalmente, visa a aferir o comportamento dos custos reais em função dos custos orçados, êle dirá respeito, principalmente, à administração.

Não existe, portanto, um só custo para tôdas as finalidades, sendo essa, talvez, a maior condição de relatividade na determinação dos custos fabris.

O comportamento dos fatôres da produção é geralmente aferido mediante emprêgo de padrões minuciosamente elaborados para cada produto ou grupo dêles, pertencentes a uma mesma linha de produção. Qualquer tendência para subestimar ou sobreestimar êsses padrões irá distorcer os resultados esperados, na medida em que os dados referentes à gestão industrial vão sendo coligidos e processados. A condição absoluta de equilibrio para determinado período de tempo é a de que o resultado favorável inicial seja gradativa e proporcionalmente compensado por um resultado desfavorável, até que o primeiro seja anulado completamente no fim do periodo. Se considerarmos que tal precisão seria obra do acaso, não nos seria difícil identificar a relativa aplicação de padrões aos custos fabris. Nem mesmo nas economias mais estáveis, em que se conseguem padrões bem resistentes, isso seria possível. E' provável que, dentro de certos limites, os resultados sejam satisfatórios. A título de ilustração, introduzimos três gráficos de variações de custos, relacionadas a custos fabris padrões e reais. Na figura 1 estamos pressupondo uma sobrestimativa do padrão; na figura 2, uma subestimativa, enquanto que na figura, 3 , um equilibrio absoluto.
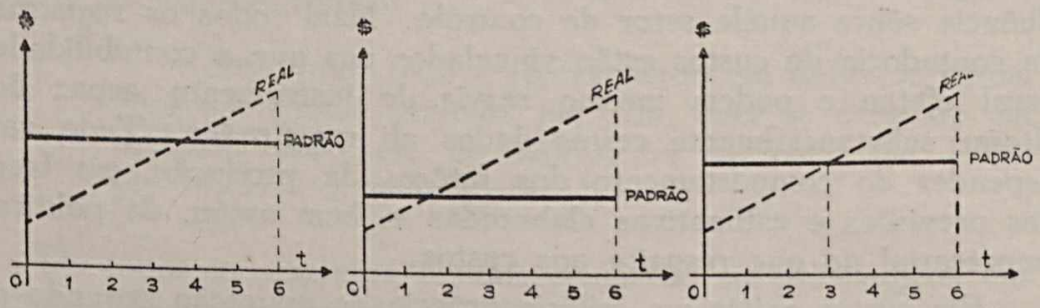

Já nos referimos à noção simplista de tabular os custos elementares de um produto para, então, chegar ao custo total. Na realidade, existe algo mais do que uma simples operação matemática de acumulações de produtórios. Referimo-nos ao processo de análise dos elementos que realmente devem ser tabulados. São muito comuns as acumulações que, de exato, só têm o cálculo. A quantidade abonada pela engenharia de projetos para a con- 
fecção de uma peça, as variações de custo unitário decorrentes de novas entradas de matéria-prima, a exata matéria-prima a utilizar, os estragos informados pela engenharia de fabricação e bem assim, os tempos improdutivos gastos nessa produção, as horas unitárias por unidade de peça ou de produto acabado, os insumos de mão-de-obra direta com beneficiamentos de matériaprima e de peças semi-acabadas, as transferências verificadas de um a outro processo de fabricação, os apontamentos de mão-de- obra direta em diferentes ordens de produção, os débitos e créditos de tôda a sorte decorrentes de distribuições (assessements) entre componentes fabris, podem contribuir, e geralmente assim é, para a distorção dos custos e, conseqüentemente, do resultado das operações. Via de regra as emprêsas costumam abandonar certos contrôles, como por exemplo, a contratação de um apontador que separe as horas de mão-de-obra direta por êsse e aquêle processo de produção, tendo em vista que seria mais econômico estabelecer um padrão de horas por tipo de produto e distribuir as horas totais pagas ao operariado direto, proporcionalmente à produção de cada linha no fim de um periodo, geralmente o contábil. Por outro lado, a maior produção decorrente de técnicas mais avançadas e de sucessivas racionalizações, poderia compensar certos gastos não incorporados ao custo do produto, justificando assim a decisão da emprêsa em abandonar certos contrôles, por excessivos. Em custos tudo é relativo, e não seria demais concluir pela relatividade daquilo que desejam expressar.

\section{A relatividade no processo de centralizar, descentralizar}

\section{e delegar}

A centralização e a descentralização de funções estão, igualmente, na dependência de certos condicionantes, de tal sorte que a formulação de critérios de ordem geral, para uma decisão naqueles sentidos, dificilmente poderia abranger a totalidade de casos.

Para centralizar ou descentralizar não basta a vontade de fazê-lo, simplesmente. Aquêle que tem autoridade para descentralizar e não o faz por estar obedecendo a uma norma interna emitida pelas autoridades superiores, como pode, também, achar-se capacitado a realizar uma centralização bem ampla. Entende-se a acumulação de atribuições por uma só pessoa, ainda, quando a pessoa que tem autoridade para delegar não dispõe de funcionários em condições de desempenhá-las satisfatòriamente, no pleno interêsse do grupo funcional.

Seria licito admitir como fato natural tôda a centralização que tivesse por objetivo a maximização de satisfações e, também, tôda descentralização que atingisse tal fim. E' preciso considerar, 
porém, que a condição de máximo para determinadas circunstâncias e em função de determinadas pessoas não é, necessàriamente, a mesma em tôdas as situações. Um prefeito pode conseguir o máximo razoável de satisfações dentro da comunidade que administra, por ter efetuado uma ampla descentralização nas responabilidades administrativas. Se cada um dos munícipes conhece o seu papel no seio da coletividade, e os membros da administração, munícipes também, conseguem dotar a máquina governamental de um poder dinamizador voltado para a maximização de satisfações, dificilmente haveria insucesso administrativo, dentro das reais possibilidades do municipio, é claro. Essa comunidade ideal, porém, longe está de existir. Se o prefeito de uma localidade vizinha - bem menor em superfície, em população e em recursos materiais de tôda a sorte - , pretende realizar uma descentralização nos moldes efetuados pelo seu colega, nada indica que possa obter um sucesso equivalente. Talvez, descentralizando certas responsabilidades mais do que outras, êle atingisse resultado semelhante. FAYOL procura esclarecer êsse assunto na seguinte exposição:

"A centralização em si, não é um sistema de administração nem bom nem mau, podendo ser adotado ou abandonado à vontade dos dirigentes ou das circunstâncias: existe sempre em maior ou menor grau. O problema da centralização ou descentralização é uma simples questão de medida". (24) (O grifo não é do original).

E logo adiante:

"Se o valor do chefe, sua fôrça, inteligência e experiência, a rapidez de sua percepção lhe permitem estender bastante sua ação, êle poderá levar longe a centralização e reduzir seus auxiliares a simples agentes de execução. Se, ao contrário, mesmo conservando o privilégio de determinar as diretrizes gerais, êle prefere recorrer mais à experiência, ao critério, aos conselhos de seus colaboradores, pode efetuar uma ampla descentralização". (25) Um chefe de familia pode delegar a sua espôsa e a seus
filhos certas responsabilidades no lar e, quando o faz, admite por
certo que não há outra alternativa. certo que não há outra alternativa. Se o desempenho das atri-

(24) HENRY $\mathrm{F}_{\mathrm{AYOL}}$ - Administração Industrial e Geral, págs. 44 e 45.
(25) Ibidem. 
buições delegadas não é satisfatório, dificilmente há de avocá-las a si. Êle pode ou não, também, delegar à espôsa a responsabilidade de arcar com parte das despesas domésticas se, evidentemente, tem essa necessidade e antevê uma possibilidade para isso. Sendo assim, a vontade de descentralizar ou centralizar tem muito que ver com a capacidade de fazê-lo. Mas FAyol nos fala em "medida", em "fôrça", em "inteligência" e em "experiência", têrmos que encerram uma relatividade também. A divisão do trabalho nem sempre justifica uma delegação. $O$ ato de delegar implica em duplo endôsso de responsabilidade: pelo delegante e pelo delegado. Embora possa ocorrer a delegação das partes transmissiveis, a suposição é a de que ela não se evidencia absoluta em todos os casos, pela simples razão de que o transmissivel para um pode não ser para outro. O delegante pode julgar-se apto a transmitir mas é preciso que o delegado sinta igual segurança também. Medir uma responsabilidade através da "fôrça", da "inteligência" e da "experiência" é uma questão puramente relativa. E' certo que a delegação importa em divisão do trabalho, mas nem em tôda divisão do trabalho deve ocorrer uma delegação. Um trabalho pode ser dividido sem ocorrer a transmissão das partes que julgamos elementares. Muitas delas hão de ser desempenhadas pela mesma pessoa. O que vale aqui é a suposição de que é capaz de fazê-lo, e sòmente isso.

Quem delega assume a responsabilidade pela coisa delegada, ainda que perante seus próprios interêsses. O diretor-presidente de uma sociedade anônima costuma delegar aos demais diretores certas atribuições de gestão, atento à evidência de que uma excessiva centralização poderia resultar em prejuízo para o bom desempenho dos trabalhos. Êle, diretor-presidente, fica responsável perante os acionistas e credores por todos os atos realizados na sua gestão. Se, porém, é proprietário também, responsabiliza-se perante seus próprios interêsses. Numa sociedade qualquer, todos os homens são delegantes e delegados, simultâneamente. Ser social por natureza, o homem permanentemente troca delegações com seus semelhantes e, aquêle que aparentemente é o delegante fica na condição, também, de delegado. $\mathrm{Na}$ escala de valores humanos, os menos favorecidos simplesmente delegam aos mais capazes, tanto quanto possível, a responsabilidade de governá-los, numa imposição natural pela sobrevivência da sociedade.

Entendemos, finalmente, que não basta colocar o problema em têrmos de vontade e de capacidade para que as centralizações e descentralizações se efetivem. Acreditamos, igualmente, no fator oportunidade, sem excluir absolutamente outros que possam contribuir para uma decisão final. Podemos manifestar uma vontade e possuir a capacidade em recursos de tôda a ordem para efetuar 
uma centralização ou descentralização, mas o que verdadeiramente contribui para o ato é a oportunidade de praticá-lo. A vontadc nos desperta o interêsse e a capacidade habilita-nos a desejar e a promover $o$ ato, mas sòmente a oportunidade nos vai permitir o ensejo de consumá-lo. E' bem verdade que, isoladamente ou em companhia de um e outro dos condicionantes, ela não seja suficiente para tanto.

\section{A relatividade nos principios de organização}

Todo comportamento humano se manifesta através de ações conscientes e através da personalidade que habita a "anima" de cada um de nós, numa reação aos incessantes estímulos que nos imprime a sociedade. Formada que é de homens, o sociedade procura estabelecer certos principios gerais e normas de conduta, numa garantia à sua própria sobrevivência. E' imprescindivel que o homem, ser social por natureza, aceite êsses principios como verdades indiscutiveis e fundamentais, se pretende interar-se no grupo.

No estudo da Organização difícilmente encontraremos um autor que não tenha enunciado seus "principios", exceção, talvez, dos chamados "sociólogos da organização", segundo nos lembra BeAtriz Wahrlich, em sua tese sôbre as principais teorias de organização.

Cesar Cantanhede elaborou um quadro comparativo dos "principios" de organização, introduzindo-o na segunda edição de sua obra "Curso de Organização do Trabalho".

Catheryn Seckler Hudson, comentando os "princípios" de organização, observa que:

“... são ferramentas nas mãos do organizador ou administrador. Devem ser conhecidos, mas não devem ser usados indiscriminadamente ou sem um cuidadoso julgamento. E' preciso discutir a validade e aplicabilidade de cada principio em face dela. Nunca se deve presumir que todos os principios se apliquem igualmente a tódas as situações". (26) (O grifo não é do original).

Se foram considerados "verdades fundamentais sôbre as quais outras se baseiam" (27) ou, simplesmente, critérios fundamentais

(26) Catheryn S. Hudson - Suimula de aula de Eurico Siqueira, sob título "Principios Fundamentais de Organização", pág. 1.

(27) Webster - Citado por Beatriz Wahrlich no "Caderno" n" 42 pág. 11 . 
ou, ainda, "guias de ação" (28), não vamos discutir neste tra. balho. O certo é que êles não podem passar despercebidos, uns mais do que outros, evidentemente, aos que administram emprêsas. O que importa para nós é, principalmente, mostrar a relatividade de alguns princípios enunciados e, assim mesmo, em número muito reduzido dêles.

Princípios da divisão do trabalho - O princípio da divisão do trabalho costuma ser interpretado segundo o desdobramento de qualquer coisa materializável: um órgão, uma tarefa ou dificuldade, uma idéia.

Suponhamos que a divisão de um trabalho permita o seu desempenho em bases mais suaves, atendendo a uma condição máxima inerente ao homem - a de procurar obter o maior bemestar possível com o minimo dispêndio de energias, no melhor conceito dos fisiocratas. Ora, o problema não está na decomposição pròpriamente dita, mas no ponto exato em que se deva paralisá-la. E' preciso considerar que o método divisional é condicionado pelo "alcance de contrôle". W. GuLIck se refere a êsse princípio, quando estabelece a seguinte comparação:

"Exatamente como a mão do homem só pode alcançar um número limitado de teclas de um piano, assim também, a mente e a vontade de um homem, só podem alcançar um número limitado de contactos administrativos..." (29)

Outro condicionante à divisão de um trabalho é o que se refere ao método a ser adotado no desdobramento. A divisão do trabalho não impõe uma condição geral de que as parcelas elementares devam ser tôdas iguais, em quantidade, e principalmente, em grau de dificuldade. Seria absoluta porque limitada a uma só finalidade, se assim fôsse. Naturalmente que a resultante das dificuldades elementares será a própria dificuldade geral, e todo desdobramento elementar tem muito que ver com os demais componentes que the sucedem e antecedem em complexidade e quantidade. A primeira condição é, portanto, de flexibilidade, e não de rigidez. Outro condicionante seria o que se refere à limitação do desdobramento sob o ponto-de-vista utilitário. Entender útil uma parcela elementar qualquer para justificar a possibilidade de um desdobramento poderia ser danoso. Em determinadas circunstâncias e segundo, principalmente, a natureza dos elementos que

(28) ISNARD G. DE FREITAS - Súmula de aula de Eurico Siqueira, sob o título "Conceito de Principios", pág. 1.

(29) Gulick, W. -- Notes on Thecry of Organization, in Papers on the Science Administration, pág. 7. 
vão ser desdobrados, a parcela elementar considerada útil não o será em tôdas as situações e por tôdas as pessoas. Seria o caso, por exemplo, daquele setor que apresentasse o seguinte panorama: um funcionário que aprontasse a máquina de escrever e outro que lhe entregasse o papel em branco, outro que recebesse o documento original e o transmitisse ao datilógrafo; outro ainda que acentuasse a necessidade de uma revisão no trabalho e outro que efetivamente o revisasse, outro que retirasse o papel da máquina, porque a função do datilógrafo é a de datilografar e, finalmente, outro que aprovasse o trabalho datilografado e o despachasse.

Uma última condição seria a relacionada à capacidade de subdividir um trabalho. Embora possa existir a vontade de fazê-lo é imprescindivel que os membros que recebem sob responsabilidade as diversas parcelas elementares, estejam aptos a desempenhá-las satisfatòriamente.

A divisão do trabalho deve pressupor, enfim, uma série de fatôres, entre os quais o homem, indiscutivelmente, o que mais contribui para a maior ou menor utilização e praticabilidade do "principio".

Principio da simplicidade - Dentre os "princípios" mencionados por William B. CoRnell, está o da simplicidade. O autor sugere a eliminação das atividades consideradas desnecessárias e o tratamento mais simples e prático das necessárias. O problema está, contudo, no que deve ser simplificado. Evidentemente, nem tôdas as atividades podem merecer um tratamento simplista. As equações matemáticas são uma forma simplista de resolução de problemas, mas o simples para um nem sempre assim é para outro. Entendemos o simples pela identificação do complexo, ou composto, de que nos fala Renné Descartes. Sendo assim, atividades podem ser consideradas simples ou complexas indiscriminadamente, variando essa concepção, é claro, segundo circunstâncias, fatos e elementos em discussão. A operação de uma máquina qualquer pode ser considerada simples para o especialista que já a manipula há algum tempo. Um novo operador, porém, pode entendê-la complexa nos primeiros dias. Admitir simples uma operação pode evidenciar uma observação pessoal, sem qualquer sentido genérico.

Principio da coordenação - Impõe-se a coordenação numa emprêsa atendendo-se à necessidade de estabelecer uma harmonia para o conjunto. Coordenar para $\mathrm{F}_{\mathrm{AYOL}}$ é "ligar, unir, harmonizar todos os esforços e todos os atos". (30) Referindo-se a

(30) Henry Fayol - Citado por Benedicto Silva em Textos Selecionados - V, pág. 79 . 
fatos que podériam ser observados numa emprêsa bem coordenada, êle ressalva, contudo:

"E' preciso convir que essas três condições nem sempre são cumpridas, pois pode-se ( $\mathrm{sic}$ ) observar em certas emprêsas, os seguintes sinais de uma incontestável descoordenação:

a) $\ldots$

b) $\ldots$

c) $\ldots$

d) Cada serviço ignora e quer ignorar os outros, como se fôsse êle mesmo, o objetivo e a razão de ser, sem se inquietar com os serviços vizinhos nem com o conjunto da emprêsa.

\section{e) $\ldots$}

f) Ninguém pensa no interêsse geral". (31)

Admitindo a necessidade de coordenação de todos os esforços e atos das emprêsas, FAYOL admite, também, nessa ressalva, uma relatividade no comportamento dos órgãos que devem encetar uma ação coordenadora. Desde que a coordenação se manifesta através de ações humanas, ficamos em dúvida quanto aos resultados absolutos que ela possa gerar. Estabelecer um perfeito entrosamento das unidades orgânicas da emprêsa não é tarefa das mais fáceis e, ainda que os resultados não sejam desabonadores, é preciso considerar que as ações humanas se manifestam, também, através de um psiquismo que, na realidade não é, e nem pode ser uniforme. Sendo assim, resta-nos admitir a relatividade dos resultados por boa norma das emprêsas.

Principio do contrôle - Aferir os resultados reais em função dos previstos é o principal objetivo de um contrôle. O primeiro obstáculo, contudo, é averiguar a praticabilidade e a contempotaneidade do contrêle que se deseja instituir.

Um contrôle de recebimentos muito comum é aquêle que separa as funções de um "caixa" das que o setor contábil executa. Manipular dinheiro é função do "caixa"; proceder registros é função de terceiros dentro da emprêsa. Por outro lado, o registro de contas e letras a pagar deve ser efetuado por elementos que não tenham a responsabilidade de emissão de cheques e processamento de "vouchers". O cheque, por sua vez, não deve ser assinado pela mesma pessoa que o preencheu e, se possivel, por um tesoureiro, e não pelo "caixa".

(31) HENRY FAYroL - Administração Industrial e Geral, pág. 138. 
Um contrôle seria absoluto se não permitisse em nenhum momento e em nenhuma situação, qualquer distorção dos resultados previstos. Subdividir um trabalho em função das necessidades da emprêsa e, particularmente, da utilidade que essa divisão pode oferecer é o que dá origem a um contrôle.

No exemplo descrito acima admitiriamos útil o contrôle estabelecido, desde que êle permitisse a obtenção de um resultado satisfatório, com um mínimo de danos possiveis. Evidentemente, ao instituílo no papel, consideramos tôdas as possibilidades de fraude e procuramos contorná-las, tanto quanto possivel. Nem por êsse motivo elas deixam de ser absolutamente viáveis. No caso, um conluio possibilitaria a irregularidade. Não se trata de limitar o alcance de contrôle, apenas, mas admitir sua relatividade. Em determinadas circunstâncias e segundo os elementos reais que devem ser controlados, êle poderia ser considerado satisfatório, mas nunca absoluto. Sempre existiria uma melhor maneira de fazer as coisas, quer seja atèndendo aos interêsses da emprêsa, quer não. O bem e o mal estão sempre presentes e se confundem diàriamente. Finalmente, o contrôle deve ser também, contemporâneo, isto é, deve variar em função dos elementos e dos fatos existentes no momento. Controlar o que não tem mais razão de ser dentro da emprêsa seria burocratizar demasiadamente os serviços. E' o que nos lembra. A. Nogueira de Faria (32) quando diz:

"O excesso de organicidade é tão prejudicial quanto a falta de organização".

Resta-nos saber, porém, o que é supérfluo e o que não é, naturalmente cutro assunto que mereceria uma discussão capaz de nos conduzir à relatividade, mais uma vez, de tudo quanto existe no campo da Organização.

Princípio da emulação - $\mathrm{O}$ estímulo à maior ou melhor produção já vem sendo adotado com certa freqüência pelas emprêsas. Nas indústrias, particularmente, êle decorre de uma economia de tempo ou de uma quantidade maior do que um limite fixado. A rigor, abona-se um tempo ou uma quantidade ao operariado para realização de uma tarefa. Se o tempo efetivamente realizado pelo trabalhador é menor do que o tempo abonado, ou se a quantidade efetivamente produzida é maior do que a fixada, êle faz jus ao prêmio. Ora, a relatividade está, justamente, na fixação do limite máximo de tempo realizado pelo trabalhador e mesmo, na quantidade teto a partir da qual faria êle jús ao in-

(32) A. Nogueira dE FARIA - Estrutura das Organizações Econômicas, pág: 15 . 
centivo. Se considerarmos que a eficiência seria representada por uma economia de tempo decorrente da diferença entre o abonado e o realizado, teríamos que admitir a relatividade dessa concepção, se para tôdas as situações. Se o tempo realizado é nulo, por exemplo, não haverá prêmio algum, e mesmo se é muito reáuzido em relação ao padrão fixado poder-se-ia supor certo esgotamento nas energias do trabalhador, na realização de um esfôrço que se incompatibilizaria com a qualidade do produto acabado. Matemàticamente, sendo $s$ o salário do operário a tempo normal, $i$ a taxa unitária de mão-de-obra direta aplicada e $t$ o tempo efetivo de realização do trabalho, e $T$ o tempo abonado para efeito de comparação, teremos:

$$
\mathrm{s}=\mathrm{it}
$$

A economia de tempo a que já nos referimos seria obtida da seguinte expressão:

$$
\frac{\mathrm{T}-\mathrm{t}}{\mathrm{T}}=1-\frac{\mathrm{t}}{\mathrm{T}}
$$

Se atribuirmos uma taxa monetária pela eficiência obtida, chegaremos ao prêmio unitário por unidade de tempo $t$ :

$$
\left(1-\frac{\mathrm{t}}{\mathrm{T}}\right) \mathrm{i}=\mathrm{i}-\frac{\mathrm{it}}{\mathrm{T}}
$$

Sendo $t$ o tempo efetivamente despendido pelo operário na realização de sua tarefa sujeita a prêmio, o valor adicional ao seu salário normal será de:

$$
P=\left(i-\frac{i t}{T}\right) t=i t-\frac{i t^{2}}{T}
$$

Derivando êsse prêmio total, êle será máximo quando o tempo efetivamente realizado fôr exatamente a metade do tempo abonado. Dessa forma, teremos:

$$
\begin{aligned}
& \frac{d P}{d t}=i-\frac{2 i t}{T} e \frac{d^{2} P}{d t^{2}}=-\frac{2 i}{T} \ldots \begin{array}{c}
\text { menor do que zero } \\
\text { (condição de máximo) }
\end{array} \\
& i-\frac{2 i t}{T}=0 ; i=\frac{2 i t}{T} ; i T=2 i t \text {, donde: } T=2 t e,
\end{aligned}
$$


finalmente:

$$
t=\frac{T}{2}
$$

O salário total do operário, portanto, seria igual a:

$$
S=s+P=i t+i t-\frac{i t^{2}}{T}=2 i t-\frac{i t^{2}}{T}
$$

Sendo assim, a taxa unitária global considerada para remuneração do operário seria dada pela operação:

$I=\frac{S}{t}=\frac{2 i t}{t}-\frac{i t^{2}}{t}=2 i-\frac{i t}{T}$

Analisemos esta expressão, tendendo-a para limites:

$$
\lim _{t} 2 \mathrm{~T}-\frac{\mathrm{it}}{\mathrm{T}}=2 \mathrm{i}-\frac{\mathrm{iT}}{\mathrm{T}}=\frac{2 \mathrm{iT}-\mathrm{iT}}{\mathrm{T}}=\frac{\mathrm{iT}}{\mathrm{T}}=\stackrel{\mathrm{i}}{=}
$$

isto é, quando o tempo efetivamente realizado é igual ao tempo abonado para realização da tarefa, a taxa unitária não vem majorada de prêmio algum. E' exclusivamente, a fixada em contrato de trabalho para o operário.

$$
\lim _{\mathrm{t}-2 \mathrm{~T}} 2 \mathrm{i}-\frac{\mathrm{it}}{\mathrm{T}}-2 \mathrm{i}-\frac{2 \mathrm{iT}}{\mathrm{T}}=\frac{2 \mathrm{iT}-2 \mathrm{iT}}{\mathrm{T}}=\frac{\mathrm{O}}{\mathrm{T}}=\underline{\mathrm{O}}
$$

representando uma taxa absolutamente nula, o que, evidentemente, não oorre em parte alquma.

$$
\lim \quad 2 i-\frac{i t}{T}-2 i-\frac{O}{T}=2 i, 0 \text { que nos parece um }
$$

absurdo matemático, tendo em vista que, na verdade, não houve participação alguma do operário no processo produtivo, não fazendo êle jus ao prêmio, evidenemente, nem ao salário normal tampouco

$$
\lim _{t-2 T+d t} 2 i-\frac{i t}{T}=2 i-\frac{i(2 T+d t)}{T}=\frac{2 i T-2 i T-i d t}{T}-\frac{i d t}{T}
$$

outra interpretação matemática sem expressão alguma. Mesmo considerando que o operário realizou um trabalho em tempo superior a duas vêzes o abonado, êle não deixaria de perceber sua remuneração. O pressuposto teórico, aqui, seria o de que êle não 
sòmente deixaria de receber um salário por horas normais de serviço, mas, também, recolheria, a título de indenização ao seu empregador, a parcela correspondente ao tempo improdutivo que despendeu fora do tempo padrão.

Principio da especialização - Nesse princípio o pressuposto é o de que se deve treinar o "agente" de tal forma que êle possa tornar-se, efetivamente, um técnico no trabalho que desempenha. O problema está, justamente, no que deva ser considerado um especialista. Elle deveria ser, naturalmente, o que resolvesse todos os problemas referentes à sua especialização, certamente com facilidade e dentro do menor prazo possivel. E' certo que a especialização impõe a necessidade de contemporaneidade, e tôdas as atividades humanas possibilitam um constante enriquecimento de seus respectivos conteúdos. A condição tempo é fundamental, não resta a menor dúvida, porque é no seu decorrer que novos conhecimentos poderão ser ou não incorporados aos que a função especializada já domina. O especialista que não se atualiza deixa de ser contemporâneo com a matéria a que se dedica e perde, naturalmente, sua condição de técnico. Por outro lado, um especialista jamais poderia relacionar um problema a uma solução verdadeiramente contemporânea, se não teve a oportunidade de enriquecer o seu conhecimento sôbre a matéria.

Uma função pode ser considerada especializada e, no concêrto das demais, ser tida como a de maior evidência. Nos hospitais, é evidente que a função médica prevalece sôbre qualquer outra, assim como os problemas econômicos pedem as soluções de um economista, e os de administração, de um técnico de administração. Da mesma forma, pressupõe-se que o médico obstetra não interfira no setor do médico cardiologista. São especializações distintas que exigem esforços distintos também. Um médico é um médico apenas na sua função e um técnico de administração também, nos setores de sua especialidade. Inverter as posições para improvisar, agraciar ou mesmo, prejudicar, é causar sérios danos. Um dos problemas de inadequado aproveitamento do técnico de administração, por exemplo, é o de nem sempre lhe permitirem as circunstâncias, a possibilidade de se acercar de bons assessôres, particularmente em setores que exigem estudos mais especializados.

Também no processo de admissão de um especialista, a rela. tividade se impõe, sem dúvida alguma. Aspectos puramente técnicos, às vêzes, submetem-se aos de ordem mais geral, numa im. posição que decorre de antigos conceitos sôbre cultura, e que hoje, felizmente, vão-se deixando superar pelas correntes mais contemporâneas e sensatas. Conhecemos o caso de um operador, cuja produção ultrapassava consideràvelmente o normal abonado 
para o tipo de tarefa da qual era, sem dúvida, um especialista. Êle seria admitido sob condição, atendendo às necessidades momentâneas da emprêsa, que exigia nos seus trabalhos fabris o concurso de um especialista. Antes de chegar a essa decisão, o serviço de pessoal submeteu-o a testes de conhecimentos gerais, e o resultado obtido foi dos mais desastrosos possíveis. Não fôssem as necessidades reais da emprêsa e as qualidades profissionais demonstradas pràticamente, ela o teria dispensado incon. tinenti.

\section{$\mathrm{V}$ - RESUMO}

Capitulo I - Justificamos nossa tese, baseando-nos no fato de que existe a imperiosa necessidade de reconhecer, dentro da Organização, em alguns aspectos seus que julgamos mais quotidianos e conhecidos, a relatividade que lhes é inerente, e que os acompanha no seu permamente evolver.

Capitulo II - Fizemos um breve relato do início da evolução universal, como a entendemos, numa tentativa de justificar as atenções do homem voltadas, principalmente, para a sua constante preocupação de satisfazer a necessidades sempre crescentes. Mostramos, ainda, que nosso conceito de Organização é o que a considera uma técnica, um instrumento de trabalho, na melhor acepção etimológica, e nos aprofundamos nesse conceito, procurando relacionar o que deve ser considerado uma verdade para conclusões científicas.

Capitulo III - Apresentamos em itens a divisão de nosso trabalho, para efeitos didáticos.

Capitulo IV - Demos início à exposição pròpriamente dita de nosso trabalho, subdividindo-o nos seguintes, intens:

1. Comentamos a relatividade na interpretação terminológica, citando apenas, alguns exemplos que têm gerado controvérsias e, conseqüentemente, alguns debates.

2. Fizemos uma breve introdução à técnica do planejamento e, em seguida, relacionamos alguns aspectos seus que julgamos menos complexos para uma exposição como esta, tema central de nosso trabalho. Assim, indicamos a relatividades:

2.1 - na estruturação de um organismo, onde identificamos três problemas relacionados a uma definição de estrutura, quais sejam:

.1 - o da identificação e possibilidade de reunião de seus elementos infra-estruturais; 
.2 - o da não introdução de um elemento que pudesse incompatibilizar-se com os demais na estrutura;

.3 - o da contemporaneidade dos elementos infraestruturais.

2.2 - na seleção de recursos materiais e humanos:

.1 - evidenciamos a importância dos recursos mentais na materialização de uma parte do organismo, lembrando que o tradicional conceito de dar o lugar certo ao homem certo encerrava, sem dúvida alguma, muita relatividade e, também, que a formação de uma equipe profissionalmente coesa não é mais o caráter predominante.

.2 - tratamos de apontar a relatividade no emprêgo de instrumentais, estabelecendo certas condições pelas quais poderiam ser considerados satisfatórios os resultados obtidos, dentre os quais:

a) o instrumental não executa seus movimentos sem a mínima participação do homem;

b) o homem pode, de certo modo, influenciar os resultados obtidos pelo instrumental;

c) o instrumental deve ser operado, tanto quanto possivel, por especialistas.

.3 - apontamos a relatividade, mais uma vez, na utilização dos materiais, imposta por certos condicionantes, dentre outros:

a) oportunidade de aquisição;

b) contemporaneidade de utilização.

2.3 - nas rotinas, nos métodos e nos sistemas, quando nos referimos à validade ou não dêles em função do espaço e do tempo de sua existência. Mostramos, ainda, que tôda alteração de um sistema poderia acarretar desequilibrios, mesmo não substanciais, nas estruturas básicas de um organismo. Observamos, também, que a relatividade no planejamento de rotinas, métodos e sistemas estava, justamente, na sua maior ou menor capacidade de resistir às mundanças de situação e que sempre é possivel prever várias situações e indicar o melhor modo de contornar as irregularidades, mas que sempre existiriam outras tantas imprevisiveis. Salientamos, finalmente, que os padrões criados no pla- 
nejamento de rotinas, métodos e sistemas são meros orientadores de um planejamento específico.

2.4 - na determinação e aplicação de padrões de desempenho evidenciamos que êles são, na realidade, aferidos tôdas as vêzes que damos início a uma operação, tarefa ou grupo delas. Observamos que um padrão não se atualiza jamais, e que desaparece dando lugar a outro, tôdas as vêzes que os elementos do quadro real, no seu processo dinamizador, forçam-no à contemporaneidade. Admitimos, assim, haver uma condição de permuta nos elementos de um padrão. Lembramos, ainda, que a preocupação dos técnicos é voltada quase que exclusivamente para os elementos susceptiveis de uma interpretação matemática, já que é caráter fundamental de resistência de um padrão a sua uniformidade, o que lho permite uma maior possibilidade de aferição dos elementos de um quadro real. Assim, fatôres de ordem fisiológica (exceção talvez, à fadiga) e, principalmente, de ordem psicológica, são desprezados.

3. Sentimos que as decisões realmente dinamizam a vida de uma emprêsa, mas não contribuem por si só para o seu coerente funcionamento em tôdas as situações. Aliciar várias soluções alternativas e dar início a um processo de eliminação das que não se compatibilizem com o problema nem com os designios da emprêsa, ou ainda que exeqüiveis, sejam incontemporâneas é, na verdade, tarefa das mais árduas, e de muita responsabilidade.

4. Estabelecemos uma comparação entre um estudo de HENRY FAyol e os objetivos de nosso trabalho, considerando que o mestre se refere às capacidades dos "agentes" e sua importância relativa, também, para a chefia. Evidenciamos, ainda, que é o interêsse o que permite a reunião de um grupo e que o chefe pode relacioná-lo a têrmos profissionais, mas que na tentativa de fazê-lo em relação a sentimentos individuais deveria admitir, por certo, uma relatividade.

5. Cuidamos de apontar a relatividade nos custos fabris, mostrando que não existe um só custo para tôdas as finalidades, e que tudo vai depender das circunstâncias e dos objetivos nesse e naquele setores de atividade da emprêsa. Igualmente, mostramos que o comportamento dos fatôres da produção é geralmente aferido segundo determinados padrões de material, mão-de-obra direta e despesas indiretas de fabricação, e que qualquer tendência para subestimar ou superestimar êsses pa- 
drões iria distorcer, naturalmente, os resultados esperados à época das reavaliações. Salientamos, também, que a condição de absoluto equilibrio dos fatôres da produção submetidos a um padrão é a de que o resultado favorável inicial fôsse progressivamente compensado, no decorrer do tempo, por outro desfavorável, mas que tal precisão seria, por certo, obra do acaso. Finalizamos êsse item concluindo pela relatividade de tudo quanto se refere a custos.

6. Salientamos que a condição de máximo para um não era, necessàriamente, para outro. Assim, tôda centralização e des^ centralização que visasse à maximização de interêsses e de satisfações deveria levar em conta, por certo, alguns condicionantes locais. Mostramos, também, que a divisão do trabalho não implica, necessàriamente, uma delegação de autoridade e de responsabilidade, tendo em vista que a delegação deve ser um ato observado pelos dois lados: o do delegante e o do delegado. Entendemos, ainda, que não basta a vontade e a capacidade para que as centralizações e descentralizações se efetivem, porque acreditamos igualmente no fator oportunidade.

7. Tratamos da relatividade em um minimo de principios, considerando que o assunto merecia um estudo à parte e, também, que ao nos referirmos à "Relatividade na Organização" no capítulo III, já limitáramos perfeitamente nosso campo de estudo para um debate. A relatividade foi, assim, apontada nos seguintes principios:

7.1 - Divisão do trabalho - Mostramos que, de início, é preciso considerar o "alcance de contrĉle", isto é, até onde se deve desdobrar uma dificuldade para que os resultados possam ser controlados com relativa facilidade. Salientamos a importância de considerar uma flexibilidade do método adotado no desdobramento, partindo do pressuposto de que a divisão do trabalho não impõe a necessidade de igualar as parcelas elementares, mas de dispô-las segundo uma seqüência lógica de complexidade e de quantidade de trabalho.

7.2 - Simplicidade - Consideramos o que deve permitir uma simplificação e o que não deve, e bem assim, o que deve ser considerado simples em tôdas as situações.

7.3 - Coordenação - Reportamo nos às palavras de FAYOL, que admite a "descoordenação" e que nos fala em "um resultado absoluto" e "um perfeito entrosamento". com certo cepticismo. 
7.4 - Contrôle - Partimos do pressuposto de que para estabelecermos um contrôle deveriamos considerar a sua praticabilidade em tôdas as situações e que desde que não contribuísse mais tarde para a distorção dos resultados poderíamos considerá-lo absoluto. Como isso não é pcssivel, todavia, segundo novos fatos, circunstâncias e elementos, poderiamos, quando muito, admití-lo útil. Salientamos, ainda, a importância de considerar o caráter de contemporaneidade de um contrôle, sem o que não teria razão de ser.

7.5 - Emulação - Mostramos aí que a relatividade estava, justamente, na fixação de um limite máximo de tempo para o trabalhador, para que faça jus a uma retribuição, a título de prêmio.

7.6 - Especialização - Apontamos a relatividade nesse princípio, ao considerar o técnico apto a resolver, sempre com facilidade e no menor prazo possivel, todos os problemas referentes a sua função ou profissão, na certeza de que esteja devidamente atualizado em todos os seus aspectos, como se o fator oportunidade não contribuísse para tanto. Mostramos, também, o que é ser um especialista, e em que condições êle seria tido por tal. Salientamos, finalmente, que uma pessoa pode entender muito de sua profissão sem que isso resolva o seu caso de admissão.

\section{VI - CONCIUSÕES}

1. Em Organização os têrmos sempre hão de flutuar ao sabor de várias interpretações.

2. Os tipos estruturais criados pelo homem são meramente convencionais, e por isso mesmo, transitórios, variando em função do tempo, do espaço e dos recursos disponiveis no momento. Nenhuma estrutura pode ser considerada tão perfeita que se adapte a tôdas as situações em.todos os instantes, e a que não evolui tende a desaparecer.

3. O homem, na sua estrutura complexa, reagindo de diferentes formas a diferentes estímulos, é um ser que se comporta segundo suas raizes sociológicas e de acôrdo com sua estrutura psicológica.

4. Reconhecer uma "anima" grupal é importante na tentativa de interação social dentro da emprêsa.

5. O instrumental não executa seus movimentos sem a minima participação do homem. 
6. O homem certo deve operar a máquina certa, mas não deve subordinar-se a ela.

7. Oportunidade de aquisição e contemporaneidade de utilização constituem uma relatividade no emprêgo de materiais.

8. Tôda alteração de uma sistema pode acarretar um desequilibrio, ainda que não substancial, na estrutura básica de um organismo.

9. Nenhuma rotina, método ou sistema pode considerar-se tão resistente às mudanças de situação, a ponto de se tornar válida permanentemente.

10. Os padrões criados no planejamento de rotinas, métodos e sistemas são meros orientadores de um planejamento mais específico.

11. Ocorre uma inversão de posições tôdas as vêzes que um padrão de desempenho tiver que aferir o comportamento de um quadro real.

12. Um padrão de desempenho não se atualiza jamais; êle desaparece quando não é mais contemporâneo e dá lugar a outro. A condição de permuta é, pois, inerente nos elementos de um padrão.

13. Fatôres de ordem psicológica não são considerados, em geral, como elementos de um padrão de desempenho, pela impossibilidade de uniformização.

14. A identificação de soluções alternativas não justifica por si só uma tomada de decisão.

15. Um chefe pode reunir um grupo pelo interêsse a uma idéia predominante, mas qualquer tentativa de relacionar êsse interêsse a sentimentos deve admitir, de início, uma relatividade.

16. Não existe um só custo para tôdas as finalidades.

17. Seria obra do acaso uma condição de equilibrio absoluto no comportamento dos fatôres da produção e, conseqüentemente, nos elementos de custos.

18. Centralizar e descentralizar não implica, sòmente, uma vontade e uma capacidade, mas pressupõe, também, a melhor oportunidade de fazê-lo.

19. A divisão de um trabalho deve ser efetuada através de um método flexivel.

20. Tôda divisão de um trabalho deve corresponder a um grau de utilidade, para ser tida por coerente.

21. Simplicidade é um têrmo muito relativo, e bem assim, as expressões: um resultado absoluto e um perfeito entrosamento. 
22. Admitir útil um contrôle é uma boa norma de colhêr resultados; admití-lo absoluto, porém, é fugir à relatividade dos fatos.

23. Estimular o subordinado é um bom principio, mas não ter a capacidade de desnivelar os elementos de aferição para diferentes trabalhos é, naturalmente, desencorajar os mais capazes e admitir a relatividade na distribuição de incentivos.

24. O técnico que não se atualiza perde a condição de especialista.

25. Todo especialista deve reconhecer certa relatividade na aplicação de novos conhecimentos, se êle não teve oportunidade de assimilá-los inteiramente e de testá-los pràticamente.

$$
\text { VII - Bibliografia CONSUltadá }
$$

1. Livros:

1.1 - Estrutura das Organizações Econômicas - Nogueira de Faria, A.

1.2 - Curso de Organização do Trabalho $-2^{\text {a }}$ edição Cantanhede, C.

1.3 - Organização Cientifica da Produção - Anderson e Schenning.

1.4 - Management and Morale - Roethlisberger.

1.5 - Administração Industrial e Geral - Fayol, H.

1.6 - Advanced Management - Kubli, H.

2. Monografias e revistas:

2.1 - Cadernos de Administração Pública, n 42 - Beatriz M. de Souza Wahrlich.

2.2 - Textos Selecionados - Parte V, da E.B.A.P.

2.3 - Revista do Serviço Público, de fevereiro de 1946.

2.4 - Súmulas de aulas de Eurico Siqueira.

2.5 - Revista do I.D.O.R.T., de outubro de 1961.

2.6 - Papers on the Science Administration. 